\title{
От детерминизма к квазидетерминизму в логике и вне логики*
}

\author{
Виталий Юрьевич Ивлев \\ МГТУ им. Н.Э. Баумана. \\ Российская Федерация, 105005, г. Москва, 2-я Бауманская ул., д.5, стр.1. \\ E-mail: vitalijivlev@yandex.ru
}

\author{
Юрий Васильевич Ивлев \\ МГУ им. М.В. Ломоносова. \\ Российская Федерация, 119991, г. Москва, Ломоносовский пр-т, д.27, корп.4. \\ E-mail: ivlev.logic@yandex.ru
}

\begin{abstract}
Аннотация: Рассматривается переход от однозначной обусловленности в логике, социальном познании и естествознании к неоднозначной обусловленности. Формулируется принцип квазифункциональности для логики и принцип квазидетерминизма для социального, естественнонаучного и технического знания. В познании, природе и социуме между явлениями имеет место не только отношение однозначной обусловленности, но и отношение неоднозначной обусловленности, т .е., в частности, определенная причина может вызывать не только определенное следствие, но и, при одних и тех же условиях, в одном случае одно определенное из нескольких возможных следствий, а в другом случае - другое. В логике принцип функциональности выражался в представлении логических терминов в качестве функций, а принцип квазифункциональности - посредством квазифункций. Квазифункция - это соответствие, в силу которого некоторый объект из определенного подмножества множества, являющегося областью определения квазифункции, соотносится с некоторым объектом из определенного подмножества множества значений квазифункции. Частными случаями квазифункции являются функция, а также полная неопределенность (хаотичность). Примером квазифункциональной логики является минимальная модальная логика $S_{m i n}$. Другими примерами таких логик являются трехзначная квазиматричная логика $S_{r}$; четырехзначные квазиматричные логики $S_{a}^{-}, \ldots S_{i}^{+}$. На основе принципа квазифункциональности предлагается разработать абстрактные и реальные квазиавтоматы. Если между сигналом на входе и сигналом на выходе автомата имеет место функциональная зависимость, то в квазиавтомате эта зависимость является квазифункциональной. При этом система квазиавтоматов может
\end{abstract}

\footnotetext{
* Статья представляет собой расширенную версию тезисов выступления на I Конгрессе РОИФН, опубликованных в электронном виде: Ивлев В.Ю., Ивлев Ю.В. От детерминизма к квазидетерминизму в логике и вне логики // История и философия науки в эпоху перемен: сб. науч. ст.: в 6 т. Т. 1. [Электронный ресурс]. М.: РОИФН, 2018. C. $80-83$.

(С) Ивлев В.Ю., Ивлев Ю.В.
} 
выражать зависимость функциональную. Ставится задача применить принцип квазидетерминизма в биологии при описании случайности, рассмотреть с этой точки зрения функционирование нервных сетей, развитие в социальной сфере и других областях познания и объективной реальности. Предлагается на основе принципа квазифункциональности пересмотреть техническое, естественнонаучное и социальное знание.

Ключевые слова: однозначная обусловленность, неоднозначная обусловленность, квазифункция, квазифункциональная логика, неоднозначная обусловленность в науке

Для цитирования: Ивлев В.Ю., Ивлев Ю.В. От детерминизма к квазидетерминизму в логике и вне логики // Логические исследования / Logical Investigations. 2018. Т. 24. № 2. C. 92-99. DOI: 10.21146/2074-1472-2018-24-2-92-99

Под детерминизмом будем понимать следующую обусловленность какого-либо явления другим явлением: всегда, когда есть определенное явление и определенные условия, существует другое определенное явление. Частным случаем такой обусловленности является причинно-следственная обусловленность (определенная причина при определенных условиях вызывает определенное следствие). Под квазидетерминизмом будем понимать следующее: в познании, природе и соииуме межсу явлениями имеет место не толъко отношение однозначной обусловленности, но и отношение неоднозначной обусловленности, m .е., в частности, определенная причина может вызыватъ не толъко определенное следствие, но и, при одних и тех же условиях, в одном случае одно определенное из нескольких возможсных следствий, $\boldsymbol{a}$ в другом случае - другое. Будем считать частным случаем квазидетерминизма детерминизм, то есть предлагаем обобщить понятия детерминизма до понятия квазидетерминизма.

Om детерминизма $к$ квазидетерминизму в логике. Современная логика создавалась как логика детерминистская. Принцип детерминизма выражался посредством принципа функциональности - логические термины представлялись в качестве функций. Так, при определении, например, конъюнкции Я. Лукасевич и С. Клини при значениях «случайно» членов конъюнкции самой конъюнкции приписывали значение «невозможно» (первый) и значение «случайно» (второй), хотя почти очевидно, что два случайных события вместе могут быть как невозможными, так и возможными. В начале шестидесятых годов Н. Решер ввел выражение «квази-истинностно функциональная логика» [Rescher, 1962]. Фактически, хотя без определения, он ввел понятие квазифункции. Однако построенная им логика оказалась не квазифункциональной. Так, ситуацию «то ли истина, то ли ложь» он рассматривал как отдельное значение. Квазифункциональная (квазиматричня) логика основывается на принципе квазифункциональности: логические термины интерпретируются в качестве квази- 
функций. Квазифункция - это соответствие, в силу которого некоторый объект из определенного подмножества множества, являющегося областью определения квазифункции, соотносится с некоторым объектом из определенного подмножества множества значений квазифункции. Частным случаем квазифункции являет функция. Примерами квазифункциональных логик являются: (1) минимальная модальная логика $S_{\min } ;(2)$ трехзначная квазиматричнаяя логика $S_{r} ;(3)$ четырехзначные квазиматричные логики $S_{a}^{-}, \ldots S_{i}^{+} ;(4)$ деонтические логики [Ивлев, 1972, Ивлев, 1973, Ивлев, 1985].

Замечание. В последние годы квазиматричная (квазифункциональная) логика стала разрабатываться не только в России (под названием «недетерминистская логика»). В некоторых работах учитываются отечественные результаты. Так, в статье [Coniglio и др., 2015] есть разделы: 2. Ivlev (1988) systems and Nmatrices, c. 21-27; 4. More Ivlev-like systems and Nmatrices, с. 34-40. В статье [Omori, Skurt, 2016] есть параграф: 3.3. A discussion on the result of Ivlev, c. 827, 828 .

Квазидетерминизм в биологии используется, например, при характеристике, случайности. Основными видовыми случайностями являются: классическая случайность - явление, которое неоднозначно детерминировано сущностью предмета, системы; функциональная случайность признак является случайным, если условиями существования его носителя неоднозначно детерминировано или не детерминировано выполнение определенных функций носителем признака; случайность по обстоятельствам явление, существование или возникновение которого неоднозначно детерминировано внешними обстоятельствами [Ивлев, 1997].

Особым видом случайности является изменение генофонда в небольших изолированных популяциях, называемое «дрейфом генов». Эту случайность можно пояснить «нарушением принципов отбора» из генеральной совокупности в «выборку», как бы производимого самой природой [Ивлев Ю.В., Ивлев В.Ю., 2017].

Нервные сети. Гипотетически нейрон можно представить в качестве квазиавтомата, имеющего, в частности, один вход и один выход. На вход нейрона поступает какой-то сигнал из подмножества, например из $\{n, c\}$, возможного множества $\{n, c, i\}$ сигналов. На выходе нейрон выдает какойто один сигнал из подмножества, например из $\{n, i\}$. Пусть имеются два нейрона, на выход которых поступает один и тот же сигнал $c$. Тогда на вход системы нейронов, состоящей из двух новых нейронов, поступит либо сигнал $c$, либо сигнал $i$, если предположить, что эти два последних нейрона описаны формулой, соответствующей конъюнкции. Таким образом, поведение нейронов может быть не определено или определено лишь частично, а поведение нейронной сети может быть определено полностью, может быть 
определено частично, а может быть совсем не определено. Возможно, что в таком поведении нейронов заключается объяснение интуиции: мозг работает как машина, которая хотя и является сложной, но все же конечной, ее работа не осознается, и результаты получаются на выходе иногда правильные, а иногда - нет.

Абстрактные и реалъные квазиавтоматъ. Между сигналом на входе и сигналом на выходе автомата есть функциональная зависимость. В квазиавтомате зависимость квазифункциональная. На вход поступает какой-то сигнал из подмножества множества возможных входных сигналов. На выходе возникает какой-то сигнал из подмножества множества возможных сигналов. Пусть имеется множество таких квазиавтоматов. Выходными сигналами являются перемещения самих квазиавтоматов. В данный момент времени нельзя установить место нахождения каждого из автоматов, но можно рассчитать, где будет находиться система квазиавтоматов [Ивлев, 2017].

Социалъное прогнозирование. Применение принципа квазифункциональности позволяет рассматривать возможные варианты развития в социальной сфере таким образом, что результаты развития отдельных составляющих социальной системы только частично предсказуемы, а результат развития системы в целом предсказуем полностью (а возможно, конечно, только частично).

Аргументация. О высказывании (концепции) может не быть никакого убеждения. Тогда значение высказывания 0. Более сильными значениями являются $\mathbf{y}$ t и $\mathbf{y б f ~ ( у б е ж д е н ~ в ~ и с т и н н о с т и ~ и ~ у б е ж д е н ~ в ~ л о ж - ~}$ ности). Более сильными, чем убt, являются значения убtn, yбtc, yбtC, $\mathbf{y} \boldsymbol{t} \mathbf{t}$, которые читаются соответственно «убежден, что истинно и онтологически необходимо», «убежден, что истинно и онтологически случайно», «убежден, что логически случайно», «убежден, что логически необходимо». Очевидно образование более сильных значений для убf. Отношения между высказываниями (концепциями) выражаются посредством квазифункций [Ивлев, 2003].

Заключение. Из сказанного видно, что квазидетерминизм имеет место как в природе и социуме, так и в познании. Целесообразно с этой позиции пересмотреть техническое, естественнонаучное и социальное знание.

\section{Литература}

Ивлев, 1997 - Ивлев В.Ю. Категории необходимости, случайности и возможности: их смысл и методологическая роль в научном познании // Философия и общество. 1997. № 3. С. 108-125.

Ивлев, 1972 - Ивлев Ю.В. Логика норм: дис. ... канд. филос. наук. М., 1972. 
Ивлев, 1973 - Ивлев Ю.В. Табличное построение пропозициональной модальной логики // Вестн. Моск. ун-та. Сер. 7. «Философия». 1973. № 6. С. 51-61.

Ивлев, 1985 - Ивлев Ю.В. Содержательная семантика модальной логики. М.: Изд-во Моск. ун-та, 1985. 170 с.

Ивлев, 2003 - Ивлев Ю.В. Основы логической теории аргументации // Логические исследования. М., 2003. Вып. 10. С. 50-60.

Ивлев, 2017 - Ивлев Ю.В. Методологическая функция квазиматричной (квазифункциональной) логики // Методология в науке и образовании. Материалы Всерос. конф. ун-тов и акад. ин-тов РАН. Москва, 30-31 марта 2017 г. М.: Изд-во МГТУ им. Н.Э. Баумана, 2017. С. 61-64.

Ивлев Ю.В., Ивлев В.Ю., 2017 - Ивлев Ю.В., Ивлев В.Ю. Объективное содержание логических знаний // Александр Зиновьев и актуальные проблемы логики и методологии. М.: Канон,+ 2017 . С. 92-114.

Coniglio и др., 2015 - Marcelo E. Coniglio, Luis Farinas del Cerro, Newton M. Peron Finite non-deterministic semantics for some model systems // Journal of nonClassical Logics. 2015. Vol. 25. No. 1. P. 20-45.

Omori, Skurt, 2016 - Omori H., Skurt D. More Modal Semantics Without Possible Worlds // IFColog Journal of Logics and their Applications. 2016. Vol. 3. P. 815846.

Rescher, 1962 - Rescher N. Quasi-truth functional systems of propositional logic // The Journal of Symbolic Logic. 1962. No. 27. P. 1-10. 


\title{
Vitaliy Yu. IVlev, Yuriy V. IVlev \\ From determinism to quasideterminism in logic and beyond logic
}

\author{
Vitaliy Yu. Ivlev \\ MGTU im. N. Uh. Bauman, \\ 5/1 2nd Baumanskaya st., Moscow, 105005, Russian Federation. \\ E-mail: vitalijivlev@yandex.ru \\ Yuriy V. Ivlev \\ Lomonosov Moscow State University, \\ 27/4 Lomonosovskiy prospect, Moscow, 119991, Russian Federation. \\ E-mail: ivlev.logic@yandex.ru
}

\begin{abstract}
This article is concerned with transition from determinate causation in logic, social and natural sciences to indeterminate causation in these branches of scientific knowledge. Analysis of this transition results in formulation of the principle of quasi-functionality for logic and the principle of quasi-determinism for social, natural and technical sciences. In cognition, nature and society, there is not only the relation of definite conditionality between phenomena, but also the relation of indefinite conditionality, i.e. some definite cause can induce not only a single specific consequence, but also, under the same conditions, in one case, one distinct consequence of several possible consequences, and in another case - another. In logic the principle of functionality was implemented through the representation of logical terms as functions, and the principle of quasi-functionality was implemented through quasi-functions. Quasi-function is a correspondence by virtue of which an object from a certain subset of a certain domain is related with a certain object from a certain subset of some set (from the range of the quasi-function). Special cases of quasi-functions are a functional relation and complete uncertainty (randomness). An example of quasi-functional logic is the minimal modal logic $S_{\min }$. Other examples of such logics are quasi-matrix three-value $S_{r}$ logic; four-value quasi-matrix $S_{a}^{-}, \ldots S_{i}^{+}$logics. Based on the principle of quasi-functionality, the idea of constructing abstract and real quasi-automata has been proposed. If there is a functional dependence between the signal at the input and the signal at the output of the automaton, then this dependence is quasi-functional in the quasi-automaton. The system of quasi-automatic machines can express functional dependence. Other actual problems are the application of the principle of quasi-determinism in biology to the description of contingency, the consideration from this point of view the functioning of neural networks, development in the social sphere and other areas of knowledge and objective reality. It is proposed to revise technical, natural sciences and social knowledge on the basis of the principle of quasifunctionality.
\end{abstract}

Keywords: existential graph theory, diagrams, Peirce, icon, iconicity, logic and information

For citation: Ivlev V.Yu., Ivlev Yu.V. "Ot determinizma k kvazideterminizmu v logike i 
vne logiki" [From determinism to quasideterminism in logic and beyond logic], Logicheskie Issledovaniya / Logical Investigations, 2018, Vol. 24, No. 2, pp. 92-99. DOI: 10.21146/20741472-2018-24-2-92-99 (In Russian)

Acknowledgements. The paper is an expanded version of the abstract, published in the I Congress of RSHPS Proceedings in electronic form: Ivlev V.Yu., Ivlev Yu.V. "Ot determinizma k kvazideterminizmu v logike i vne logiki" [From determinism to quasideterminism in logic and beyond logic], in: Istoriya $i$ filosofiya nauki $v$ epokhu peremen [History and philosophy of science in the era of change]. 6 Vols. Vol. 1. Moscow: RSHPS Publ., 2018, pp. 80-83.

\section{References}

Coniglio, et al., 2015 - Marcelo, E. Coniglio, Luis Farinas del Cerro \& Newton, M. Peron. "Finite non-deterministic semantics for some model systems", Journal of non-Classical Logics, 2015, Vol. 25, No. 1, pp. 20-45.

Ivlev, 1997 - Ivlev, V.Yu. "Kategorii neobkhodimosti. sluchaynosti i vozmozhnosti: ikh smysl i metodologicheskaya rol v nauchnom poznanii" [Categories of necessity, chance and possibility: their meaning and methodological role in scientific knowledge], Filosofiya $i$ obshchestvo [Philosophy and society], 1997, No. 3, pp. 108-125. (In Russian)

Ivlev, 1972 - Ivlev, Yu.V. Logika norm [The Logic of Norms]. Phd thesis. Moscow, 1972. (In Russian)

Ivlev, 1973 - Ivlev, Yu.V. "Tablichnoye postroyeniye propozitsionalnoy modalnoy logiki" [Tabular construction of propositional modal logic], Vestnik Moskovskogo universitetayu. Seriya 7 «Filosofiya». [Bulletin of the Moscow University. Series 7 "Philosophy"], 1973, No. 6, pp. 51-61. (In Russian)

Ivlev, 1985 - Ivlev, Yu.V. Soderzhatelnaya semantika modalnoy logiki [The semantics of modal logic]. M.: Publishing House of Moscow University, 1985. 170 pp. (In Russian)

Ivlev, 2003 - Ivlev, Yu.V. "Osnovy logicheskoy teorii argumentatsii" [Fundamentals of the Logical Theory of Argument], Logicheskiye issledovaniya [Logical Investigation], 2003, Vol. 10, pp. 50-60. (In Russian)

Ivlev, 2017 - Ivlev, Yu.V. "Metodologicheskaya funktsiya kvazimatrichnoy (kvazifunktsionalnoy) logiki" [Methodological function of quasi-matrix (quasifunctional) logic], in: Metodologiya $v$ nauke $i$ obrazovanii [Methodology in science and education], Materials of the All-Russian Conference of Universities and Academic Institutes of the Russian Academy of Sciences. Moscow, March 30-31, 2017, Moscow: Izdatelstvo MGTU im. N.E. Bauman, 2017. pp. 61-64. (In Russian)

Ivlev Yu.V., Ivlev V. Yu., 2017 - Ivlev, Yu.V., Ivlev, V.Yu. "Obyektivnoye soderzhaniye logicheskikh znaniy" [Objective content of logical knowledge], in: Aleksandr Zinovyev $i$ aktualnyye problemy logiki i metodologii [Alexander Zinoviev and actual problems of logic and methodology]. M.: Canon +, 2017, pp. 92-114 (In Russian) 
Omori, Skurt, 2016 - Omori, H., Skurt, D. " More Modal Semantics Without Possible Worlds", IFColog Journal of Logics and their Applications, 2016, Vol. 3, pp. 815846.

Rescher, 1962 - Rescher, N. "Quasi-truth functional systems of propositional logic", he Journal of Symbolic Logic, 1962, No. 27, pp. 1-10. 